\title{
Novice Teachers' Challenges and Coping Strategies in Qatari Government Schools
}

\author{
Shaikha R. AL-Naimi \\ Qatar University, Doha, Qatar \\ https://orcid.org/0000-0002-3230-8478 \\ Michael H. Romanowski \\ Education Research Center, College of Education, Doha, Qatar \\ https://orcid.org/0000-0003-2454-3571 \\ Xiangyun Du \\ Education Research Center, College of Education, Doha, Qatar \\ https://orcid.org/0000-0001-9527-6795
}

\begin{abstract}
This study examined the challenges novice teachers encountered in Qatari government schools and the coping strategies they adopt. A qualitative study was conducted using semi-structured interviews with 15 novice teachers during their initial years of teaching. The findings demonstrated that most participants faced several personal challenges and other challenges within and beyond the school. Findings also indicated that these teachers confronted these challenges using various coping strategies. The challenges facing novice teachers include teaching and classroom, government, and administrative, and professional challenges. Novice teachers' coping strategies included individual internal peace strategies, active communication, and changing environment. Finally, based on these findings, suggestions are provided to support novice teachers' long-term success in Qatari government schools or similar contexts.
\end{abstract}

Keywords: Novice Teachers; Challenges; Coping Strategies; Governmental Schools

\section{Introduction}

The novice teacher completed a university-based teacher education program with less than five years of teaching (Kim \& Roth, 2011). Michel (2013) suggests that novice teachers could be viewed as strangers in a new land since they are unfamiliar with the school's culture and norms, and they must navigate through planning, teaching, assessing, and an assortment of other responsibilities and demands. Corcoran (1981) describes novice teachers' initial years as a "transition shock" or as a "not knowing" period, where new teachers discover that their 
idealism of teaching is quite different from the realities of the classroom. More specifically, novice teachers are characterized as having a 'survive and thrive' encounter (Fantilli \& McDougall, 2009) or 'sink or swim' experience during their first-year teaching in which they experience new and unknown situations (Sabar, 2004). These experiences have led to significant numbers of teachers exiting the profession. Literature has documented the ongoing trend of leaving the profession citing between 25 to 50 percent of novice teachers resigning within the first five years (Bang, Kern, Luft \& Roehrig, 2007; Massengill, Mahlios \& Barry, 2005).

In Qatar, the government schools have difficulty recruiting and retaining new teachers. Novice teachers in Qatar face a shifting educational policy landscape, with many reform issues prevailing within the education system (Chaaban \& Du, 2017). Qatar's education reform, known as "Education for a New Era," moved from a centralized to a decentralized system, converting government schools to independently operated schools with limited government control. The implementation of this change began in 2002, and the first independent schools opened in 2004. The Independent School System modified the curriculum and the criteria used to determine quality teachers (Khodr, 2011; Nasser, 2017). As Qatar is undergoing educational reforms designed to transform into a knowledge society, teachers play an essential role in enforcing educational innovation (Akyol, 2016). Therefore, teachers' stability and job satisfaction are of particular importance for the quality of teaching and learning.

Nevertheless, Qatar's novice teachers are being expected to bear the same teaching loads and responsibilities as their more experienced colleagues (Alloh, Hasan, Du \& Romanowski, 2019). This study demonstrated that novice (less than five years of teaching experience) and experienced (between five or more years of teaching experience) teachers reported high levels of EE burnout. Furthermore, the first year of a teacher's career is significant because it provides insight into whether the teachers will remain in the classroom (Sözen, 2018; Wang, Odell \& Schwille, 2008; Watt \& Richardson, 2008). Thus, it is essential to examine the challenges that novice teachers face and how they attempt to cope (Chaaban \& $\mathrm{Du}, 2017)$ to improve current practices and teachers' work conditions. This study aimed to examine the challenges facing novice teachers and explore the coping strategies employed to accustom themselves to daily work in Qatari government schools. The study focused on understanding novice teachers' experiences and gaining insight into their coping mechanisms rather than assessing their performance.

\section{Literature Review}

\subsection{Novice teachers' challenges}

Research supports that novice teachers' challenges are intrinsic to the teaching profession and conditions of the school environment (Glickman, Gordon \& RossGordon, 1995; Gordon, 1991; Lieberman \& Miller, 1984). Cody (2009) suggests that novice teachers struggle with various challenges upon graduation from teacher education programs designed to prepare them for teaching. However, novice teachers face challenges seldom addressed in their professional preparation. 
Nevertheless, beginning teachers, in particular, face a wide range of challenges to navigate during their first years in the classroom (Ergunay \& Adiguzel, 2019).

Besides, they face multiple challenges that are fundamental to the teaching profession and the school environment's workplace conditions. New teachers realize that curricula and materials designed for them in their professional programs differ from those used in the school context (Lee, 2017). Previous studies examining beginning teachers outline the challenges related to many tasks associated with the school setting. For instance, increased demands beyond pedagogical tasks, frequent curriculum changes, additional administrative work, a growing need for technological competence, and increasing diversity among students (Tschannen-Moran \& Hoy, 2007; Cody, 2009; Le Maistre, \& Pare, 2010; Öztürk \& Yildirim, 2013; Collie \& Martin, 2016).) all confront novice teachers.

More specifically, the pedagogical challenges that beginning teachers may include classroom management and organization, demands of teaching face loads, student diversity and motivation, assessment, and addressing individual student problems (Anhorn, 2008; Kelly \& Northrop, 2015; Liu, 2007; Quinn \& Andrews, 2004; Schlichte, Yssel \& Merbler, 2005; Yost, 2006). Improving student participation in classroom activities and developing supportive teaching materials is a challenge (Emmer \& Stough, 2001). Roehrig and Pressley (2005) found that dealing with individual student differences and challenges posed by students were most cited as challenges, not just by first-year teachers, but also by their experienced counterparts.

Furthermore, many novice teachers lack the advanced skills that experienced teachers have acquired for years. Unlike experienced teachers, novices are not as organized as their experienced counterparts and had limited pedagogical content knowledge. They cannot predict where in the curriculum, students could have difficulty, and therefore, struggle to make effective decisions around prioritizing content coverage (Gaikhorst, Beishuizen, Roosenboom \& Volman, 2017). Novice teachers often take more time in the planning process for each lesson than the experienced teachers, due to a wide variety of lesson characteristics including timing, content, scope, pacing, instructional and behavioral management concerns, and sequencing activities. Therefore, novice teachers see planning as time-consuming compared to other core tasks they must fulfill for their students (Koni \& Krull, 2018).

Another aspect that impacts novice teachers' experiences is contextual challenges. Novice teachers' understanding of their school contexts, for example, the collegial climate, influence their intentions to continue with their teaching career (Borko \& Livingston, 1989; Coburn and Russell, 2008; Coleman, 1988; Penuel, Riel, Joshi, Pearlman, Kim \& Frank, 2010). School policies and administration demands could also influence novice teachers' feelings about job conditions and satisfaction (Coburn \& Russell, 2008; Ivanitsky, 1998; Penuel, Riel, Joshi, Pearlman, Kim \& Frank, 2010; Powell, 2014). 
There are also societal factors that influence teachers. The social status of teachers can be an essential area of how teachers perceive their profession. For example, in a society where teachers are highly respected and hired as civil servants with lifelong job security such as in Japan and Germany, teachers experience higher satisfaction with their jobs and enjoy a relatively higher social status than teachers in other countries where the status of teachers was lower (Fwu, \& Wang, 2002). These factors influence the novice teachers' reaction to their first teaching position experiences and play a role in their choice to stay or leave the profession.

\subsection{Novice teachers' coping strategies}

When facing challenges and stress, teachers subjectively perceive the school environment's quality, and the support available to them is vital for dealing with a stressful situation (Montgomery \& Rupp, 2005). Developing strategies to cope with stress and adversity is vital to ensure teacher retention (Prilleltensky, Neff \& Bessell, 2016).

Coping strategies are categorized into several areas. There are direct-action strategies that attempt to eliminate the source of stress (Austin, Shah \& Muncer, 2005; Sharplin, O'Neill \& Chapman, 2011). Direct-action strategies can include seeking assistance, obtaining information, accessing professional development opportunities, connecting with others and reflecting, reframing, and establishing boundaries (Sharplin, O'Neill \& Chapman, 2011). Research indicates that directaction strategies seem to alleviate job distress and are efficient in reducing teacher burnout (Pogere, López-Sangil, García-Señorán \& González, 2019).

Palliative strategies attempt to reduce internal or emotional reactions (Austin, Shah \& Muncer, 2005; Pogere et al. 2019). These include adopting a goal focus, establishing psychological boundaries, using humor and maintaining health and well-being, and maintaining relationships. Finally, avoidant and distancing coping strategies lead to withdrawal from the cause of stress, depersonalization, and emotional fatigue, and lack of accomplishment (Chan \& Hui, 1995; GustemsCarnicer, Calderón \& Calderón-Garrido, 2019). However, these coping strategies increased psychological symptoms (Chan, 1998; Pogere et al. 2019).

Regarding the Gulf Cooperation Council (GCC) countries, there are fewer studies that address novice teachers. Dickson, Riddlebarger, Stringer, Tennant and Kennetz (2014) studied novice teachers in the United Arab Emirates, reporting that novice teachers leaving the profession were high. These new teachers were challenged with classroom management issues, coping with their new workload, managing lesson planning, navigating inter-cultural relationships with colleagues, and balancing work with their demanding home lives. Chaaban and $\mathrm{Du}$ (2017) investigated the challenges and coping strategies of five novices and five experienced teachers in Qatari governmental schools. They reported differences in the challenges facing experienced teachers and their novice colleagues and the different coping strategies used by these teachers. Their findings indicated that novice teachers in Qatar governmental schools used several of the above-mentioned direct-action strategies, while experienced teachers used direct-action and palliative strategies. It was evident that new 
teachers also employed strategies to seek help, mainly to deal with classroom management problems and manage a heavy workload.

\section{Background}

The Qatar National Vision 2030 depends on the fundamental goal of a knowledgebased economy (Al-Mansoori \& Koç, 2019). Education is the key to developing and unlocking human potential and building a sustainable society. The Ministry of Education and Higher Education (MOEHE) and Qatar's leaders have recognized the value of educating the country's citizens and residents in order to ensure future social, political and economic success (Hassen, 2020). Since Qatar places education as a national priority, it is worthwhile to examine the problems and challenges novice teachers face providing possible recommendations that enable schools to develop a supportive atmosphere.

Qatar's Ministry of Education Education's (MOEHE) Strategic Plan of 2017-2022 has been implemented in the education system. One aspect of the plan centers on developing a system that assures the recruitment of highly qualified teachers and ensures their continued professional development to effectively implement and achieve student-centered learning education and the achievement of 21st-century skills (Strategic Plan of Ministry of Education and Higher Education, 2017)., Qatari government schools still facing a severe lack of qualified teachers (Ahmed, 2018; Nasser, 2017; Romanowski, Cherif, Al Ammari \& Al Attiyah, 2013). Chaaban and $\mathrm{Du}(2017)$ posits that the numerous organizational changes and educational reform demands have also increased the challenges and stress for novice teachers as they struggle to address new pedagogical practices and the use of digital technology in the classroom.

Statistically, Qatar's government schools contain 3,721 female Qatari teachers working in government schools, compared to 230 male teachers; in contrast, there are around 10,937 non-Qatari female teachers and 3,660 non-Qatari male teachers. Candidates for teaching positions must have earned a bachelor degree in the specialization required.

The data also reveals the number of novice teachers who enrolled in governmental schools, including Qatari teachers from different grade levels and majors numbered around 183, while the non-Qataris were 155, with both genders included (The Ministry of Development Planning and Statistics, 2017). Interestingly, Qatari teachers receive several economic benefits, including bonuses and allowance related to the years of experience, qualifications, and yearly performance evaluation results. However, the burnout level in Qatar's schools remains high and the schools suffer from a high rate of shortages of both female and male new Qatari teachers (Alkhateeb, 2013; Alloh et al. 2019; Ridge, Kippels, Shami, \& Farah, 2014).

\section{Methods}

This research aims to understand novice teachers' experiences as they face challenges in school environments and their coping strategies, rather than assessing their performance. Therefore, a qualitative research design was 
developed because it provides a deeper understanding and offers insight into teachers' lived experiences (Kvale, 1996; Punch \& Oancea, 2014; Creswell \& Miller, 2000). This small-scale qualitative study used semi-structured interviews to examine novice teachers' challenges and coping strategies. In particular, the study was guided by the following research questions:

1) What challenges beginning teachers in Qatar encounter during their first years' teaching experiences?

2) What coping strategies they developed to overcome these challenges?

\subsection{Participants}

The target population for this research was novice teachers at diverse levels of the Qatar government schools. Participants had teaching experience ranging from 0 to 3 years. The sample included novice teachers currently teaching in government schools and teachers who had left the teaching within the first three years. Both Qatari and non-Qatari residents who were born and raised in Qatar selected for this study.

Snowball sampling was used to select participants. The sample included fifteen teachers, nine females, and six males. Eight of the participants are current teachers, while seven left the teaching profession. Concerning the participants' teaching levels, seven taught or are teaching at the primary level, six at the preparatory two have experience at several levels. Of the 15 teachers, 12 are Qatari nationals, with the remaining three born and raised in Qatar. Six teachers were contracted by "Teach For Qatar" and organizations that recruit individuals from various careers as teachers providing a two-year contract to teach in the Qatari government schools (Teach For Qatar, 2019). For detailed participant information, see Appendix A.

\subsection{Data Collection and Analysis}

Semi-structured interviews were used for data collection to capture the lived meanings and experiences of the subjects' everyday world (Kvale, 1996; Kvale \& Brinkmann, 2015). The interviews centered on these teachers' challenges during the early years of their teaching. Participants convey in their own words their situations and from their unique perspectives. Each interview was guided by an interview guide developed based on the research question that directs this study. Two interview guides were utilized for this study (Appendix B provides details) - one designed for teachers currently working in schools and another for those who left teaching. Fifteen interviews were conducted in Arabic, transcribed, and then translated. All interviews were audio-taped, with each interview lasting approximately 30-60 minutes. Throughout the interviewers probing was used to further develop teachers' responses and collect relevant examples when possible.

A thematic bottom-up approach was employed for data analysis in this study, which allows for the discovery of unconsidered themes that produce new meanings (Namey, Guest, Thairu \& Johnson, 2008). The interview transcripts were analyzed using thematic analysis guided by the research questions (Fereday $\&$ Muir-Cochrane, 2006). The recorded interviews were transcribed and manually coded to identify emerging themes, subthemes, and patterns reported in detail in the next section. Data analysis was conducted collectively, with individual 
analysis by all coauthors first followed by collective discussion before consensus was reached to improve the study's credibility. The analysis included several rounds of readings of the transcripts. In the first reading, the thematic analysis approach was applied to analyze the supporting and constraining factors early career teachers experienced and the challenges in Qatar's government schools. Identified patterns, themes, and sub-themes were coded to answer the research question for this study. Participants' quotes were used to develop the findings. To develop a compelling narrative and interpretation of the data and ensure confidentiality and identity protection, each teacher is identified using an interview number and $\mathrm{F}$ for female and $\mathrm{M}$ for male.

\section{Findings}

\subsection{Challenges facing novice teachers in Qatar}

1) What challenges beginning teachers in Qatar encounter during their first years' teaching experiences?

The challenges faced by novice teachers in Qatari governmental schools can be classified into three interrelated themes namely, teaching challenges, challenges created by government policies and administrative demands, and professional challenges.

\subsubsection{Teaching and classroom challenges}

There are a variety of teaching challenges novice teachers faced during their initial years of teaching.

First, these teachers reported many challenges they faced concerning the tasks of teachers. Classroom management was discussed by ten teachers (T2, T4, T6, T7, T8, T10, T11, T12, T14, and T15) who considered classroom management a key challenge. They indicated that classroom management issues included students not following instructions or arguments between students during an instructional period. More importantly, these teachers reported that they lacked classroom management techniques. Several female teachers (T12, T14, and T15) suggested that some administrators would not receive punishments if there was poor behavior among the students and that misbehaving students posed a challenge for novices who lacked classroom management techniques. However, teachers often discussed classroom management in terms of class sizes, indicating that these management problems would be reduced if they have lower class sizes.

Second, the number of classes and size was reported as a fundamental challenge that led to other teaching problems. Teachers (T2, T4, T6, T7, T8, T10, and T11) indicated that a large number of classes that they were assigned their first year was too much for them and what I made it more difficult was the high number of students in each class (33-40) or more. This concern is expressed by one teacher (T6) who stated:

at first the most challenging thing was the workload that they gave me, as it was my first year. They should not give me these many periods - they gave me 12 periods per week. Yes, most teachers teach as much, and it is not easy, but I was new. They could have given them to me little by little, 4 periods/week, one section, then two sections, then three, and then I 
would be able to manage 4 sections. Giving me 12 periods/week at the beginning was hard.

Large class sizes for these novice teachers created several instruction problems, such as not covering all the learning objectives for lessons. Also, teachers indicated that the high numbers of students in the classes prevented the teacher's productivity. For example, for the writing lessons, the English teacher wanted to have the students write two to three drafts of each writing prompt in the class and then have the students share their writing pieces with their peers. Besides, the teacher needed time to review student writings and correct mistakes in-class. T4 described the problem of class, size stating:

I wanted to make a student improvement plan. So, students' levels are A, $B$, and $C$, and I take the $C$ group because they are the most in need for improvement while giving the other two groups exercises. I am alone in the class, so everyone is calling for me, but I want to focus on $C$ group, see and touch stuff to understand, and need time... To be able to produce a well-educated generation. 20-25 students is good for the teacher to be able to focus on each student.

According to participants, principals did not consider novice teachers' needs when it came to the load or the number of students in a class.

Finally, the participants addressed the challenges they faced with planning lessons. Seven among fifteen participants in this study, namely (T1), (T2), (T9), (T11), (T12), (T13), and (T14), mentioned the planning issues arose from various perspectives. Many teachers were disappointed with the standardized lesson plan, which they viewed as unfair and restricted their planning abilities somehow. T9 stated:

They [MOEHE] standardize the lesson plans, so everyone delivers the same lesson, asks the same questions. I tried once to change something, and they did not like it in the department, regardless if it was better or not. So, this standardization is good for teachers to raise their levels, but it is also bad for creative teachers and dulls their skills.

Teachers in governmental schools do not have much freedom or independence to alter lesson plans, and they are required to hand the lesson plans to their department coordinators weekly, as requested. The teachers' interview data shows that their department coordinator controls the selected educational objectives and the instructional strategies for each daily lesson. Teachers also could be questioned if they did not finish the required educational objectives on time.

Moreover, addressing individual differences among students was another challenge for the participant teachers because of their limited teaching field experience. As T15 explained:

Several students enter preparatory schools not knowing how to read, multiply or add numbers. They did not cover the standards from the previous year. .. students move up a grade without completing the 
standards and every time a student goes up a level, the burden is on the teacher; should he teach the student from zero or just give the current year's curriculum. It was how the students treated you and you handle them, it was the biggest challenge as I taught 8th grade, which is the most difficult level to teach.

Several teachers $(\mathrm{T} 4,8,10,11,12$, and 15) reported difficulties in dealing with students' academic levels within the same classroom and applying strategies to address the individual needs.

\subsubsection{Government and administrative demands}

The amount of additional work required by the MOEHE and the school administration was a challenge and the primary source of stress and perceived pressure. For example, ten out of the fifteen participants (T1, T3, T4, T5, T6, T10, T11, T12, T13, and T15) reported that governmental policy decisions were the second biggest challenge that novices faced beyond the context of the school itself. The majority of teachers were displeased with policymakers' overnight decisions in the MOEHE, which translated into a sudden regulatory change in their schools. Female teachers (T12, T13, and T15) who left the field voiced disappointment that the MOEHE does not listen to its citizens' suggestions, and in a related way, the Ministry does not trust Qatari competence in further developing its educational system.

Participants claimed that in taking the opinions of outside experts who do not study in Qatari governmental schools, the MOEHE is letting outside experts shape national policies instead of teachers from within the system. Participants indicated the value in taking the ideas of competent Qatari professionals who understand Qatari history, society, culture, and have previous experiences in the country's schools. As T5 said:

This year it is a new curriculum. They should have given us a chance to examine it, you know, or give it to the teachers a year before getting good feedback. Instead, they bombarded us with new curricula and asked for new plans, new formats, and new everything without notice or research or workshops. Just like that, take it and get going.

Finally, four teachers (T1, T2, T6, and T9) reported that some of the demands the Ministry of Education and Higher were the main reasons behind feelings of selfdoubt, which had the effect of lowering their self-confidence in their teaching abilities.

Many of these teachers were unaware of the additional administrative demands assigned by school administrators. Most thought that they would only have a teaching load and responsibilities connected to students. Nine among the fifteen participants (T1, T2, T3, T5, T6, T8, T10, T11, and T14) mentioned that the school administrators ask teachers to take on an extra workload is not directly related to their primary teaching responsibilities. Some teachers were surprised by the tasks they were asked to perform, as female teacher T1 commented:

There are many administrative demands. For example, in my last school, I used to look after the girls during their break time. ... And If I didn't 
want to come, the administrators, I have to sign a warning paper. ... For us as teachers, the academic vice-principal, she demands a lot.... If we do not want to do something, she gives warnings, so I feel terrified.

The school administrators ask teachers to take on extra workload, taking time from their primary teaching responsibilities. In addition, some teachers were surprised by the tasks they were asked to perform. T10 stated, "there is a written item that the teacher should do whatever the administrators required them to say. This means that the teacher should do everything without questioning why arguing with the school administration." T14 describes what work is involved stating:

The essential tasks for me are to prepare, plan, get my material and tools ready for the class; these things already take much of my effort besides paperwork, grading, and other mandatory tasks. But, then, come other tasks like preparing for the morning line-up, and after morning line-up, write a report, and during the line-up do this and that, so many things, events, anything they put such a big load on teachers. Even the scientific research is considered a big load because it is mandatory. . . all at once, the teacher is a social worker, an officer, a principal; it is all in the classroom. The teacher is responsible for everything.

Participants reported that was these demands created significant personal stress. Four female teachers (T1, 2, 12, and 15) believed they shared similar feelings of stress or exhausted throughout their workdays and at home. Two of them expressed that this stress was caused by school administrators and students in the classroom space. One teacher (T1) described having feelings of panic all day in school because of the warning letters that she may receive from the school administrators if she did something wrong. She stated:

I am already exhausted with all the preparing, and they come and tell me take them to the morning line up or go with them to..., so many tiring tasks, it would be better if they left the teacher to do what she came to do, in the classroom.

The other two female teachers were stressed from the teaching system in government schools in general as well as paperwork and exhaustion arising from administrative demands.

\subsubsection{Professional Challenges}

There are several what we term professional challenges reported by many of these teachers. There was a sense that several teachers lacked competence and a sense of the lack of self-efficacy during their first months of teaching. Three participants (T2) (T8) and (T14) discovered in their first months of teaching that they were unable to master their teaching goals with their students due to a lack of competence and skills. T14 stated:

my first year was really hard. I needed to work a lot on myself, by myself. So, the load was on me, I had to develop myself; I worked hard and never expected anything from the school. Yes, some people offered help, but the perception of weakness was always there. 
This teacher describes the lack of skills and the stigma associated with teachers who are not prepared or effective. Another teacher stated, "I was not good with computers, and everything was done electronically. ... I felt depressed at the beginning, I had to make PowerPoints that covered the material in a suitable way for the students." For many, novice teachers were viewed as experienced teachers with the expectation of possessing well-developed teaching skills. Furthermore, two of these teachers (T2) and (T14) reported that they had received insufficient support in developing competencies required in the teaching profession.

One concern raised by these novice teachers was their preparation to be teachers. Five teachers (T1, 5, 9, 12, and 13) suggested that they faced the challenge of an existing gap between what they learned in the preservice education and the reality they faced in their classrooms. These teachers argued that they received the knowledge, practices, and beliefs about teaching practices from their undergraduate studies, but they found it challenging to experience a disconnect between their studies and practices and experiences in schools. Two teachers who eventually left teaching reported that it was difficult to reconcile what they experienced in the college and what occurred in schools. For teachers (T2, 3, 4, and 6) who were graduates from a local College of Education, they reported that what they learned during their studies was useful and helped them in their daily routine in the school environment. They thought they were effective in their roles and had a sound knowledge of the subject or curricula.

Regarding the schools' attempt to possibly reduce this gap by providing professional development programs for teachers, teachers (T1, 2, 3, 9, 12, 13, and 14) suggested that the school workshops dealing with instructional strategies and classroom management tools addressed topics that they were learned in their teacher preparation programs. They suggested that the PD was not effective and appropriate for their particular challenges. T13 expressed this concern, stating:

They [the PD program] are not offering anything new. They could offer new strategies that would be great to learn, offer the latest research, global research, and apply new concepts to our classes. Instead, they teach us how to write objectives, of course we know how... they are not helping me to develop - they are just repeating old stuff.

Pertaining to the workshop in schools, several viewed these workshops as not beneficial and a waste of time after a long day of work and following multiple other meetings that day.

However, the two teachers (T7 and T8) reported that school workshops were useful, and were overall more satisfied. These teachers enjoyed attending the professional development sessions and looked forward to attending more and applying new things in their classrooms. T7 said:

we attended 4 or 5 workshops at Al Faisal Foundation; they offered a teacher package...there are plenty of courses and development workshops for those who are looking to develop themselves.

Finally, for teachers in this study, the low social status of teachers in Qatar became a challenge for several participants. Two female teachers (T5 and 15) and five male teachers (T6, T7, T8, T9, and T10) reported similar viewpoints regarding this issue. 
Female teachers were suggested that they had to earn a graduate degree to gain respect in terms of social status. Since it was difficult to study full-time, some opted to leave the profession and seek a higher degree rather than stay as a teacher.

Male teachers had suggested that teaching is not an appropriate career path for Qatari men. It seems that men in Qatar do not see teaching as a prestigious job to hold; consequently, there is a shortage of male Qatari teachers. Besides, the work culture in schools is very different from other companies. For example, the military is highly regarded in Qatari society due to special services offered to them to facilitate their transactions throughout Qatar. Likewise, they have better salaries than teachers, including healthcare and airline tickets for them and their families. Teachers only receive salaries at the end of each month. T9 describes this issue stating:

Guys here look for prestigious positions, so they look for any position with the title of manager, head, or coordinator. A teacher is... they tell me' You went into teaching?' as if it's such a low job- that's the perspective. Often, they tell me 'Are you serious? A teacher? You were an engineer!' Even my family tells me, 'You went to university to become an engineer, and you became a teacher'... they look down on the job, unfortunately.

For both genders, the low social status seems to play a role in teachers leaving, but it presents a challenge to recruiting and retaining Qatari teachers.

\subsection{Coping strategies used by novice teachers}

2) What coping strategies they developed to overcome these challenges?

The teachers reported several coping strategies that they use to deal with the challenges they face during the initial years of teaching. Twelve out of the fifteen teachers interviewed suggested an assortment of coping strategies as their first choice in dealing with schoolwork challenges. These strategies are internal peace strategies, active communication, solving problems through networking or seeking professional development outside the school, and changing schools or leaving the profession. The first strategy used by six teachers (T1, T2, T4, T12, T13, and T15) demonstrates several of what we term individual internal peace strategies. Teachers reported that they immersed themselves in activities, isolation, and taking short time to de-stress and regain equanimity. Other teachers were able to manage their emotions, health, and well-being by seeking health professionals' assistance. Also, four participants (T1, T2, T4, and T15) used several activities to relieve daily stress. For example, some of the participants used to call their best friends and share their experiences at work, which made the teachers feel refreshed and allowed them to receive some advice about the challenges they faced. Others used negative coping strategies to relieve their frustrations by bingeeating sweets, which led to an uncomfortableness with their appearance because of being overweight.

For others, isolation became a strategy for stress relief. For example, two participants (T12 and T13) who left the profession avoided the teachers' break room since it contained a very negative atmosphere. T12 stated: 
I would isolate myself from them [other faculty]. I don't react [to] their negativity; it's as if I didn't hear a thing. In this school, I sat in my own corner, [and] I left the teacher's room. [There] was so much negativity and complaining, so I had to leave the room so that they don't make me hate my work and dislike teaching.

Their coping strategy was simply to evade the teachers' room to avoid negative feelings.

The second strategy that these teachers utilized included active communication. Ten out of the fifteen participants (T1, T2, T3, T4, T5, T6, T7, T8, T9, and T14) preferred to make direct requests for help from school administrators, department coordinators, or experienced teachers whenever they wanted to learn new regulations in their schools or to solve problems they faced. Teachers said that ongoing administrative support such as the principal's open door and informal meetings with academic vice-principals and other teachers were effective in their first year. One participant describes this strategy and its effectiveness.

An experienced teacher, ... made me love my profession even more, and made it easy for me because she taught me how to reach my goal[,] which is to make the students love the subject and find it easy - not difficult. She taught me how to leave an impression on them, either morally or education-wise. (T1)

These individuals realized this strategy was useful while working with supportive administrative and academic vice-principals because they offered these novice teachers some space to voice their opinions and concerns. However, this coping strategy might be ineffective in another school setting.

An alternative strategy used by five participants (T7, T8, T9, T10, and T12) dealt with findings solutions to challenges through networking or internet searches and seeking out opportunities for professional development outside of school rather than asking anyone at their schools. Males teachers were more likely to use technology and the Internet to solve problems they faced, seek new teaching methods, and increase their knowledge of the subject. For example, a male participant tried to teach students the skills they would require later in life. The participant said he observed a student who had advanced technology skills and asked him to make a video with iMovie. The student then explained the lesson on camera, edited the video, and performed multiple other related tasks. Students appreciate such gestures, and it encouraged them. Other interview participants expressed their need for individual professional development plans with some professional development sessions in their first probationary months; therefore, participants were particularly grateful for professional development opportunities during this period.

Finally, these teachers coped with teaching by changing schools or leaving the profession. Teachers who are still in the classroom (T1 and T2) decided to change the location where they worked from one school to another, hoping to find a place that suited their teaching beliefs. One participant changed to a new school and chose to teach primary rather than preparatory and secondary levels. This participant thought that she would never teach secondary after what she went 
through in the previous school at the secondary level. However, when she transferred to a more suitable environment for students. However, some participants left the teaching profession. One teacher (T9), a new teacher in his school and new to the teaching world, was looking forward to going back to his old job as soon as he finished his two-year contract with Teach for Qatar. He said, "I worked for 8 years in QP, it's a whole different culture there ... And after I finish my two-year contract, I will go back to my previous job at the QP company." Other teachers (T10, T11, T12, T13, T14, and T15) ultimately left the teaching profession. Some teachers left to complete their master's degrees or found other places to work, such as universities or offices which did not have any teaching loads. One teacher (T12) stated:

I did a Master's of Arts in Curriculum, Instruction, and Assessment ... Now, I am looking to get my PhD and work at the College of Education ... You know, after leaving school, the administration would always contact me and tell me that the students were still asking about me. That's because there was love.

Several male teachers who finished two years of the "Teach for Qatar" contract viewed themselves as excellent engineers and knew that they would have better options in private companies, especially from a financial point of view. Males focused on the financial aspect, and therefore, they generally preferred not to continue teaching. T11 said, "When I completed my teaching assignment, I still had my salary and all the benefits from $Q P$, and I did not want to lose that. Teaching salaries, compared to the petroleum and private sectors, [are] very low."

\section{Discussion}

\subsection{Challenges}

This study explored the challenges that novice teachers' faced teaching in Qatari government schools and the coping strategies that they adopted. Qualitative data from interviews with 15 participants showed that the majority of the participants face several challenges, including teaching and classroom, government and administrative demands, and various professional challenges. Participants reported various coping strategies employed to address these challenges.

These teachers reported various challenges that are compatible with the findings Dickson et al. 2014 findings that reported similiar challenges faced by the novice Emirati teachers concerning the school environment. It is important to note that Qatar and UAE have similarities in their Arab culture and education systems, with both systems undergoing substantial educational reform and rapid changes in school every year, causing the same types of challenges to teachers' work in governmental schools. The addressed challenges were included as (1) implementing the new curriculum and (2) administrative demands, (3) classroom management, and (4) a perception of a lack of support (Dickson, Riddlebarger, Stringer, Tennant \& Kennetz, 2014; Tennant et al., 2019).

Novice teachers reported in the current study that they encounter challenges in planning the lesson plans and challenges in students' differences. This aligns with what was reported previously by Du and Chaaban (2020) that all lesson plans were identical and were restricted by MOEHE and had specific directions by subject coordinators, which created teachers' lack of understanding of PBL and 
avoided them to be creative while delivering the lessons. Although PBL and PBL addressed the individual differences among the students, teachers still had issues of a lack of motivation among Qatari schools (Al Said et al. 2019).

Several female participants in this study expressed their feelings of stress or being exhausted working at government schools, which is in line with what was reported previously by (Alloh et al. 2019) when female novice teachers in Qatari primary schools with less than five years of experience were scored high levels in their Emotional Exhaustion burnout (EE). In this study, it seems that male teachers suffered less from the burnout levels, feeling of exhaustion, and depression, which align with the findings of (Boström, Björklund, Bergström, Nybergh, Schäfer Elinder, Stigmar \& Kwak, 2020), female participants were significantly more stressed than their male colleagues, with $20.2 \%$ of female teachers reported "very much stress" compared to $4.5 \%$ of male teachers.

Concerning new policies and decisions from MOEHE, which affect instructional practices and the daily performance of teachers, some participants of this study hinted about implementing the PBL in Qatar's primary government schools as a new instructional approach in the classroom, and it is similar to a previous study obtained by Al Said et al. (2019). The study examined math teachers' beliefs regarding their roles, practices, and perceived change; half of the interviewed teachers mentioned that some of their peer teachers were resisting the change strategy and the top-down decision from MOEHE and school. They have negative attitudes toward participating in the daily practice of PBL and did not believe in the benefits of PBL that may be helpful to their students' achievement. Therefore, both the current study and the previous study concluded that the policy changes and decisions need to be better communicated if they are to be well understood by teachers and especially novices. The directives are not clear, and a meaningful discussion and improved communication would help schools offer extensive professional development for any new changes and regulations.

Novice teachers in this study lacked self-confidence and self-efficacy beliefs that could eventually cause a lower job satisfaction among teachers (Klassen, Bong, Usher, Chong, Huan, Wong \& Georgiou, 2009), it may also create barriers to professional development (Renbarger \& Davis, 2019). The novice teachers' selfefficacy beliefs will increase gradually along with the higher job satisfaction and positive energy in the profession as they gain years of experience and know their students' needs (Chaaban \& Du, 2017).

In addition, novice teachers in the current study mentioned the distinction between the pre-service teachers' programs and the reality of teachers' work in schools revealed by female and male teachers that is similar to research by Qadhi, Hendawi, Mohammad, Ghazi, Al-Dosari and Du (2020) when the interviewed teachers identified some significant challenges involved, the feeling a gap between the program and work-life; in terms of, the difficulty of using students' assessment results to provide feedback and confusing between theories of classroom strategies they learned from college and handling students in a classroom setting. The considerable gap between what novice teachers learned at 
the College of Education and the reality of the schools' daily practices, which ultimately caused participants T12 and T13 to leave the teaching field. According to Kim and Cho (2014) and Mahmood (2013), beginning teachers who experience a high reality shock tend to leave teaching in their first years.

Furthermore, male teachers preferred to work in companies with higher salaries, life insurance, and other job privileges for them and their family and this result is supported by previous literature (Hall \& Carroll, 1973; Rumberger, 1987) in that males' concern for higher salaries because male teachers are more likely to be the primary breadwinners in their households than women. This also explained why in the Gulf countries and Emirati education systems, most males who work at schools are administrator staff rather than the classroom teachers (Badri \& $\mathrm{Al}$ Khaili, 2014).

The concern for teachers' social status was isolated to Qatari male teachers in the Qatari educational system and Qatari society. As five male teachers responded in their interview answers that being teachers for males is not prestigious in Qatari society compared to professions in engineering or the military, as well as they do not have privileges such as health care and airline tickets for themselves and their families, and salaries are much less than those of engineers or military personnel. Though the literature has highlighted the importance of recruit men and there is a need for male teachers in the education system to benefit young boys from having male role models (Hansen \& Mulholland 2005; Mills, 2000; Mills, Martino, \& Lingard, 2004).

\subsection{Coping Strategies}

Regarding coping strategies, this study identified several strategies that the participant teachers utilized to deal with the multiple demands of the teaching tasks in Qatari governmental schools. In this study, strategies that included active communication tended to be the most often used strategy by the study participants. According to Barber (2020), novice teachers prefer sending given information via an email daily with $(51.9 \%)$ or in-person discussions or meetings at least monthly with $(27.8 \%)$ as active communication with administrative staff.

Another coping strategy expressed by teacher participants was finding a solution or seeking assistance, such as professional training outside the school. Male teachers in the study used YouTube and attended professional training outside the school to learn new teaching methods, considering these useful ways to get answers for problems they faced rather than asking anyone at their schools or waiting for assistance. Previous studies addressed this finding termed 'directaction strategies' or 'problem-focused coping,' and it is a traditional strategy suggested by scholars. Beers (2012) and Sharplin, O'Neill, and Chapman (2011) described earlier that beginning teachers could directly address challenges and problems by utilizing various strategies such as getting information from websites and accessing professional development without the schools' help. It is similar to male participants in the current study who graduated as engineers, and it seems that they enjoyed searching the Internet about anything related to the subject taught or students' learning in classrooms. 
Equally important was strategies that sought personal internal peace. Female participants considered individual internal peace strategies as essential ways to relieve stress. These strategies included immersion in activities, isolation, and taking a brief time out. Specifically, they would call their best friends, go to a spa or salon, and stop spending time in the teachers' room to avoid negative feelings. These personal internal peace strategies have been presented in previous studies as palliative or avoidant coping (Sharplin, O'Neill \& Chapman, 2011). The current study as well the past studies, support novice teachers to choose their own choice or way to release the stresses they feel and reduce the stress resulting from the teaching workload, including setting realistic expectations, positive thinking, blocking negative comments, pragmatism, sport, watching TV, listening to music, simply relaxing or talking, and reading (Murray-Harvey, 2001).

Finally, the working environment (to another school) and changing to other professions were also considered by some participants. Novice teachers in the study identified changing the school environment is an essential coping strategy, and since they changed their schools, they perceived high degrees of collaboration among administrators and experienced teachers and increased their level of selfefficacy. Chester and Beaudin (1996) encouraged novice teachers to convert to a collegial school culture with the opportunity for collaboration and support for beginning teachers. However, six of the novice teachers later dropped out of the profession and worked in different careers. There are four main factors regarding teachers dropping out within the first teaching years. These are the teacher's core task-related factors, individual factors, social environment factors, and socioeconomic conditions (Karsenti \& Collin, 2013). All of these factors are associated with the participant teachers who left the teaching profession.

\section{Conclusions}

In summary, the current study aimed to investigate the challenges novice teachers face and the coping strategies they employ during their first three years of working in Qatari governmental schools. The results demonstrate various, interrelated challenges novices face and that there are several coping strategies teachers use daily.

\section{Recommendations}

Based on these findings, we provide several recommendations. Institutions of higher education should provide the pre-service teachers two years of practical experience under the mentorship of an experience teacher before the completion of their undergraduate degree. This could aid in gaining knowledge and understanding more about the school environment teaching and its challenges by developing a shared vision between the program and schools. It could also prove useful to address teachers' work-related stressors, their perceptions of coercion effectiveness, isolation or rejection, and their struggles in their daily work. Therefore, it is recommended that schools assign professional mentors who can listen to novices' concerns and needs, especially in the first three years, and help them cope with these challenges. 
Novice teachers may lack planning skills, and thus, they should have extensive professional development sessions and work on evaluating, developing, and revising lesson plans by their schools or the MOEHE. This will enable beginning teachers to improve their planning and Teaching. Likewise, before implementing any new technology, the school, the Ministry of Education, and the College of Education should study teachers' and pre-service teachers' attitudes and beliefs towards this new resource. They should address how it will be integrated into the curriculum and how it will be useful for students. In addition to helping novice teachers develop, government schools could provide relevant and applicable professional development reducing the frustration and disappointment expressed by these novice teachers. Finally, teachers' social status and image play a role in occupational prestige, the recruitment, and retention of teachers and can impact the satisfaction of having a teaching career. Qatar's Ministry of Education's strategic plan and future agenda could develop a national strategy to recruit more male primary school teachers because of its educational needs and the importance of positive male role models in boys' schools.

We suggest that future studies use survey research to collect data about novice teachers gathering a large sample. Furthermore, future studies may include other perspectives, such as those of school leaders and experienced teachers.

\section{References}

Ahmed, F. B. J. (2018). Challenges of the Knowledge Society: Exploring the Case of Qatar. 17.

Akyol, B. (2016). Teacher Self-Efficacy Perceptions, Learning Oriented Motivation, Lifelong Learning Tendencies of Candidate Teachers: A Modeling Study. Eurasian Journal of Educational Research, 16(65), 1-35. https://doi.org/10.14689/ejer.2016.65.02

Al Said, R. S., Du, X., ALKhatib, H. A. H. M., Romanowski, M. H., \& Barham, A. I. I. (2019). Math Teachers' Beliefs, Practices, and Belief Change in Implementing Problem Based Learning in Qatari Primary Governmental School. EURASIA Journal of Mathematics, Science and Technology Education, 15(5). https://doi.org/10.29333/ejmste/105849

Alkhateeb, H. M. (2013). Attitudes towards teaching profession of education students in Qatar. Comprehensive Psychology, 2, 01-03.

Alloh, M. M., Hasan, M. A., Du, X., \& Romanowski, M. H. (2019). Burnout of Primary Teachers in Qatar Government Schools during an Era of Educational Reform. International Journal of Learning, Teaching and Educational Research, 18(10), 1-19. https://doi.org/10.26803/ijlter.18.10.1

Al-Mansoori, R. S., \& Koç, M. (2019). Toward Knowledge-Based Economy: Innovation and Transformational Leadership in Public Universities in Texas and Qatar. Sustainability, 11(23), 6721.

Al-Thani, T., Al-Muftah, E., Romanowski, M. H., Coughlin, C., \& Abuelhassan, H. H. (2015). Early years education in Qatar: The good practice guide in theory and practice. International Journal of Research Studies in Education, 4(5). https://doi.org/10.5861/ijrse.2015.1142

Anhorn, R. (2008). The Profession That Eats Its Young. Delta Kappa Gamma Bulletin, 74(3).

Austin, V., Shah, S., \& Muncer, S. (2005). Teacher stress and coping strategies used to reduce stress. Occupational Therapy International, 12(2), 63-80. https://doi.org/10.1002/oti.16 
Badri, M., \& Khaili, M. A. (2014). Migration of P-12 Education from its Current State to One of High Quality: The Aspirations of Abu Dhabi. Policy Futures in Education, 12(2), 200-220. https://doi.org/10.2304/pfie.2014.12.2.200

Bang, E., Kern, A. L., Luft, J. A., \& Roehrig, G. H. (2007). First-year Secondary Science Teachers. School Science and Mathematics, 107(6), 258-261. https://doi.org/10.1111/j.1949-8594.2007.tb18287.x

Barber, R. S. (2020). A CASE STUDY OF COMMUNICATIONS BETWEEN SCHOOL ADMINISTRATORS AND TEACHERS IN AN URBAN MIDDLE SCHOOL. 119.

Borko, H., \& Livingston, C. (1989). Cognition and improvisation: Differences in mathematics instruction by expert and novice teachers. American educational research journal, 26(4), 473-498.

Boström, M., Björklund, C., Bergström, G., Nybergh, L., Schäfer Elinder, L., Stigmar, K., Wåhlin, C., Jensen, I., \& Kwak, L. (2020). Health and Work Environment among Female and Male Swedish Elementary School Teachers - A Cross-Sectional Study. International Journal of Environmental Research and Public Health, 17(1), 227. https://doi.org/10.3390/ijerph17010227

Brinkmann, S., \& Kvale, S. (2015). Interviews: Learning the craft of qualitative research interviewing. Sage Publications.

Caspersen, J., \& Raaen, F. D. (2014). Novice teachers and how they cope. Teachers and Teaching, 20(2), 189-211. https:// doi.org/10.1080/13540602.2013.848570

Chaaban, Y., \& Du, X. (2017). Novice teachers' job satisfaction and coping strategies: Overcoming contextual challenges at Qatari government schools. Teaching and Teacher Education, 67, 340-350.

Chan, D. W. (1998). Stress, coping strategies, and psychological distress among secondary school teachers in Hong Kong. American Educational Research Journal, 35(1), 145163.

Chan, D. W., \& Hui, E. K. (1995). Burnout and coping among Chinese secondary school teachers in Hong Kong. British journal of educational psychology, 65(1), 15-25.

Chester, M. D., \& Beaudin, B. Q. (1996). Efficacy beliefs of newly hired teachers in urban schools. American Educational Research Journal, 33(1), 233-257.

Coburn, C. E., \& Russell, J. L. (2008). District Policy and Teachers' Social Networks. Educational Evaluation and Policy Analysis, 30(3), 203-235. https://doi.org/10.3102/0162373708321829

Cody, J. (2009). Challenges facing beginning immersion teachers. American Council on Immersion Education Newsletter, 13 (3), 1-8

Collie, R. J., \& Martin, A. J. (2016). Adaptability: An important capacity for effective teachers. Educational Practice and Theory, 38(1), 27-39.

Corcoran, E. (1981). Transition shock: The beginning teacher's paradox. Journal of Teacher Education, 32(3), 19-23. Retrieved from http://0search.proquest.com.mylibrary.qu.edu.qa/docview / 63655332?accountid=13370

Creswell, J. W., \& D. L. Miller. Determining validity in qualitative inquiry. Theory into practice, 39(3), 124-130.

Dickson, M., Riddlebarger, J., Stringer, P., Tennant, L., \& Kennetz, K. (2014). Challenges faced by Emirati novice teachers. Near and Middle Eastern Journal of Research in Education, 2014(1), 4. https://doi.org/10.5339/nmejre.2014.4

Du, X. Y., \& Chaaban, Y. (2020). Teachers' Readiness for a Statewide Change to PjBL in Primary Education in Qatar. Interdisciplinary Journal of Problem-Based Learning, 14(1). https:// doi.org/10.14434/ijpbl.v14i1.28591

Du, X.Y., Chaaban, Y., \& Mabrd, Y. A. (2019). Exploring the Concepts of Fidelity and Adaptation in the Implementation of Project Based Learning in the Elementary 
Classroom: Case Studies from Qatar. International Journal of Learning, Teaching and Educational Research, 18(9), 1-22. https://doi.org/10.26803/ijlter.18.9.1

Du, X.Y, Chaaban, Y., Sabah, S., Al-Thani, A. M., \& Wang, L. (2020). Active learning engagement in teacher preparation programmes-A comparative study from Qatar, Lebanon and China. Asia Pacific Journal of Education, 1-16. https://doi.org/10.1080/02188791.2020.1717436

Emmer, E. T., \& Stough, L. M. (2001). Classroom Management: A Critical Part of Educational Psychology, With Implications for Teacher Education. Educational Psychologist, 36(2), 103-112. https://doi.org/10.1207/S15326985EP3602_5

Ergunay, O., \& Adiguzel, O. C. (2019). The First Year in Teaching: Changes in Beginning Teachers' Visions and Their Challenges. Qualitative Research in Education, 8(3), 276. https://doi.org/10.17583/qre.2019.4016

Fantilli, R. D., \& McDougall, D. E. (2009). A study of novice teachers: Challenges and supports in the first years. Teaching and Teacher Education, 25(6), 814-825. https://doi.org/10.1016/j.tate.2009.02.021

Farrell, T. S. C. (2012). Novice-Service Language Teacher Development: Bridging the Gap Between Preservice and In-Service Education and Development. TESOL Quarterly, 46(3), 435-449. https://doi.org/10.1002/tesq.36

Fereday, J., \& Muir-Cochrane, E. (2006). Demonstrating rigor using thematic analysis: A hybrid approach of inductive and deductive coding and theme development. International Journal of Qualitative Methods, 5(1)

Fwu, B.-J., \& Wang, H.-H. (2002). The Social Status of Teachers in Taiwan. Comparative Education, 38(2), 211-224. https:// doi.org/10.1080/03050060220140584

Gaikhorst, L., Beishuizen, J., Roosenboom, B., \& Volman, M. (2017). The challenges of beginning teachers in urban primary schools. European Journal of Teacher Education, 40(1), 46-61.

Glickman, C., S. Gordon, and J. Ross-Gordon. 1995. Supervision of instruction (3rd Ed.). Needham, Mass: Allyn and Bacon.

Gordon, S. P. (1991). How to help beginning teachers succeed. Alexandria, USA: Association for Supervision and Curriculum Development.

Gustems-Carnicer, J., Calderón, C., \& Calderón-Garrido, D. (2019). Stress, coping strategies and academic achievement in teacher education students. European Journal of Teacher Education, 42(3), 375-390.

Hall, W. C., \& Carroll, N. E. (1973). The Effect of Teachers' Organizations on Salaries and Class Size, 9.

Hansen, P., \& Mulholland, J. A. (2005). Caring and Elementary Teaching: The Concerns of Male Beginning Teachers. Journal of Teacher Education, 56(2), 119-131. https://doi.org/10.1177/0022487104273761

Hassen, T. B. (2020). The state of the knowledge-based economy in the Arab world: cases of Qatar and Lebanon. EuroMed Journal of Business.

Ivanitsky, A. T. (1998). Training of personnel development in the educational collective: methodological guide. Saint-Peterburg.

Jian, W., Odell, S. J., \& Schwille, S. A. (2008). Effects of Teacher Induction on Beginning Teachers' Teaching: A Critical Review of the Literature. Journal of Teacher Education, 59(2), 132-152. https://doi.org/10.1177/0022487107314002

Karsenti, T., \& Collin, S. (2013). Why are new teachers leaving the profession? Results of a Canada-wide survey. Education, 3(3), 141-149.

Kelly, S., \& Northrop, L. (2015). Early Career Outcomes for the "Best and the Brightest": Selectivity, Satisfaction, and Attrition in the Beginning Teacher Longitudinal 
Survey. American Educational Research Journal, 52(4), 624-656. https://doi.org/10.3102/0002831215587352

Khodr, H. (2011). The dynamics of international education in Qatar: Exploring the policy drivers behind the development of Education City. Journal of Emerging Trends in Educational Research and Policy Studies, 2(6), 514-525.

Kim, H., \& Cho, Y. (2014). Pre-service teachers' motivation, sense of teaching efficacy, and expectation of reality shock. Asia-Pacific Journal of Teacher Education, 42(1), 67-81. https:// doi.org/10.1080/1359866X.2013.855999

Kim, K. A., \& Roth, G. L. (2011). Novice teachers and their acquisition of work-related information. Current issues in Education, 14(1).

Klassen, R. M., Bong, M., Usher, E. L., Chong, W. H., Huan, V. S., Wong, I. Y. F., \& Georgiou, T. (2009). Exploring the validity of a teachers' self-efficacy scale in five countries. Contemporary Educational Psychology, 34(1), 67-76. https:// doi.org/10.1016/j.cedpsych.2008.08.001

Koni, I., \& Krull, E. (2018). Differences in novice and experienced teachers' perceptions of planning activities in terms of primary instructional tasks. Teacher Development, 22(4), 464-480.

Kvale, S. (1996). InterViews: an introduction to qualitive research interviewing. Sage.

Le Maistre, C., \& Paré, A. (2010). Whatever it takes: How beginning teachers learn to survive. Teaching and Teacher Education, 26(3), 559-564. https://doi.org/10.1016/j.tate.2009.06.016

Lee, J. S. J. (2017). Hidden Challenges of Novice English Teachers in a Korean Independent School: Through an Ethnographic Lens. Qualitative Report, 22(6).

Lieberman, A., \& Miller, L. (1984). Teachers, Their World, and Their Work. Implications for School Improvement. Alexandria, USA: Association for Supervision and Curriculum Development.

Liu, X. S. (2007). The effect of teacher influence at school on first-year teacher attrition: A multilevel analysis of the Schools and Staffing Survey for 1999-2000. Educational Research and Evaluation, 13(1), 1-16. https://doi.org/10.1080/13803610600797615

Mahmood, S. (2013). "Reality Shock": New Early Childhood Education Teachers. Journal of Early Childhood Teacher Education, 34(2), 154-170. https://doi.org/10.1080/10901027.2013.787477

Massengill, D., Mahlios, M., \& Barry, A. (2005). Metaphors and Sense of Teaching: How these constructs influence novice teachers. Teaching Education, 16(3), 213-229. https://doi.org/10.1080/10476210500204887

Michel, H. A. (2013). The First Five Years: Novice Teacher Beliefs, Experiences, and Commitment to the Profession (Doctoral dissertation, UC San Diego).

Mills, M. (2000). Issues in Implementing Boys' Programme in Schools: Male teachers and empowerment. Gender and Education, 12(2), 221-238. https://doi.org/10.1080/09540250050010027

Mills, M., Martino, W., \& Lingard, B. (2004). Attracting, recruiting and retaining male teachers: Policy issues in the male teacher debate. British Journal of Sociology of Education, 25(3), 355-369. https:// doi.org/10.1080/0142569042000216990

Montgomery, C., \& Rupp, A. A. (2005). A Meta-Analysis for Exploring the Diverse Causes and Effects of Stress in Teachers. Canadian Journal of Education / Revue Canadienne de l'éducation, 28(3), 458. https:// doi.org/10.2307/4126479

Murray-Harvey, R. (2001). How teacher education students cope with practicum concerns. The Teacher Educator, 37(2), 117-132. https:/ / doi.org/10.1080/08878730109555286

Namey, E., Guest, G., Thairu, L., \& Johnson, L. (2008). Data reduction techniques for large qualitative data sets. Handbook for team-based qualitative research, 2(1), 137-161. 
Nasser, R. (2017). Qatar's educational reform past and future: Challenges in teacher development. Open Review of Educational Research, 4(1), 1-19. https://doi.org/10.1080/23265507.2016.1266693

Öztürk, M., \& Yildirim, A. (2013). Adaptation challenges of novice teachers. Hacettepe Üniversitesi Eğitim Fakültesi Dergisi, 28(1), 294-307.

Penuel, W. R., Riel, M., Joshi, A., Pearlman, L., Kim, C. M., \& Frank, K. A. (2010). The Alignment of the Informal and Formal Organizational Supports for Reform: Implications for Improving Teaching in Schools. Educational Administration Quarterly, 46(1), 57-95. https:/ / doi.org/10.1177/1094670509353180

Pogere, E. F., López-Sangil, M. C., García-Señorán, M. M., \& González, A. (2019). Teachers' job stressors and coping strategies: Their structural relationships with emotional exhaustion and autonomy support. Teaching and Teacher Education, 85, 269-280.

Pogodzinski, B., Youngs, P., \& Frank, K. A. (2013). Collegial Climate and Novice Teachers' Intent to Remain Teaching. American Journal of Education, 120(1), 27-54. https://doi.org/10.1086/673123

Powell, S. R. (2014). Examining Preservice Music Teacher Concerns in Peer- and FieldTeaching Settings. Journal of Research in Music Education, 61(4), 361-378. https://doi.org/10.1177/0022429413508408

Prilleltensky, I., Neff, M., \& Bessell, A. (2016). Teacher Stress: What It Is, Why It's Important, How It Can be Alleviated. Theory Into Practice, 55(2), 104-111. https://doi.org/10.1080/00405841.2016.1148986

Punch, K. F., \& Oancea, A. (2014). Introduction to research methods in education. Sage.

Qadhi, S., Hendawi, M., Ghazi, E., Ghazi, I., Al-Dosari, N., \& Du, X. (2020). The Impact of a Teacher Preparation Programs on Professional Teaching Competencies - Female Novice Teachers' Perspectives. International Journal of Learning, Teaching and Educational Research, 19(1), 118-135. https://doi.org/10.26803/ijlter.19.1.7

Quinn, R. J., \& Andrews, B. D. (2004). The Struggles of First-Year Teachers: Investigating Support Mechanisms. The Clearing House: A Journal of Educational Strategies, Issues and Ideas, 77(4), 164-168. https:// doi.org/10.3200/TCHS.77.4.164-168

Renbarger, R., \& Davis, B. K. (2019). Mentors, Self-Efficacy, or Professional Development: Which Mediate Job Satisfaction for New Teachers? A Regression Examination. Journal of Teacher Education and Educators, 8(1), 21-34.

Ridge, N., Kippels, S., Shami, S., \& Farah, S. (2014). Policy paper. Policy paper, 11(8).

Tennant, L., Stringer, P., Riddlebarger, J., Dickson, M., Kennetz, K. (2019). Emergence of Professional Identities of Novice Emirati Teachers. Australian Journal of Teacher Education, 44(9), 44-61. https://doi.org/10.14221/ajte.2019v44.n9.3

Roehrig, A. D., \& Pressley, M. (2005). Stories of beginning teachers: First year challenges and beyond. Catholic Education.

Romanowski, M. H., Cherif, M., Al Ammari, B., \& Al Attiyah, A. (2013). Qatar's Educational Reform: The Experiences and Perceptions of Principals, Teachers and Parents. International Journal of Education, 5(3), 108. https://doi.org/10.5296/ije.v5i3.3995

Rumberger, R. W. (1987). The impact of salary differentials on teacher shortages and turnover: The case of mathematics and science teachers. Economics of education review, 6(4), 389-399.

Sabar, N. (2004). From heaven to reality through crisis: Novice teachers as migrants. Teaching and Teacher Education, 20(2), 145-161. https://doi.org/10.1016/j.tate.2003.09.007

Schlichte, J., Yssel, N., \& Merbler, J. (2005). Pathways to Burnout: Case Studies in Teacher Isolation and Alienation. Preventing School Failure: Alternative Education for Children and Youth, 50(1), 35-40. https://doi.org/10.3200/PSFL.50.1.35-40 
Seong, J. (2017). Hidden Challenges of Novice English Teachers in a Korean Independent School: Through an Ethnographic Lens, 17.

Septiani, A., Emiliasari, R. N., \& Rofi'i, A. (2019). The Novice English Teachers' Experience: Practices and Challenges. Academic Journal Perspective: Education, $\begin{array}{llll}\text { Language, and } & \text { Literature, }\end{array}$ https://doi.org/10.33603/perspective.v7i2.2708

Sharplin, E., O'Neill, M., \& Chapman, A. (2011). Coping strategies for adaptation to new teacher appointments: Intervention for retention. Teaching and Teacher Education, 27(1), 136-146. https://doi.org/10.1016/j.tate.2010.07.010

Sözen, P. H. (2018). Challenges of Novice Teachers. International E-Journal of Advances in Education, 4(12), 278-282.

Strategic Plan of Ministry of Education and Higher Education. (2017). Retrieved from http://www.edu.gov.qa/Ar/about/Pages/Strat.aspx

Teach For Qatar. (2019). Retrieved from http://www.teachforqatar.org/en/fellowship/training-support

The Ministry of Development Planning and Statistics. (2017). Retrieved from https://www.mdps.gov.qa/en/statistics/Statistical\%20Releases/Social/Educat ion/2017/Education_Chapter_4_2017_AE.pdf

Tschannen-Moran, M., \& Hoy, A. W. (2007). The differential antecedents of self-efficacy beliefs of novice and experienced teachers. Teaching and teacher Education, 23(6), 944-956.

Wang, J., Odell, S. J., \& Schwille, S. A. (2008). Effects of teacher induction on beginning teachers' teaching: A critical review of the literature. Journal of Teacher Education, 59(2), 132-152.

Watt, H. M. G., \& Richardson, P. W. (2008). Motivations, perceptions, and aspirations concerning teaching as a career for different types of beginning teachers. Learning and Instruction, 18(5), 408-428. https:// doi.org/10.1016/j.learninstruc.2008.06.002

Yost, D. S. (2006). Reflection and self-efficacy: Enhancing the retention of qualified teachers from a teacher education perspective. Teacher Education Quarterly, 33(4), 59-76. 


\section{Appendix 1}

Table 1. Participants' Demographics

\begin{tabular}{|c|c|c|c|c|c|}
\hline Teacher & Gender & $\begin{array}{l}\text { Teaching Status and } \\
\text { Experience }\end{array}$ & $\begin{array}{l}\text { Teaching } \\
\text { Level }\end{array}$ & $\begin{array}{l}\text { Educational } \\
\text { Background }\end{array}$ & Nationality \\
\hline $\mathrm{T} 1$ & Female & $\begin{array}{l}\text { Current teacher (11 } \\
\text { months) }\end{array}$ & $\begin{array}{l}\text { Secondary and } \\
\text { Preparatory }\end{array}$ & $\begin{array}{l}\text { Bachelor Education/ } \\
\text { Islamic Studies }\end{array}$ & $\begin{array}{l}\text { Born and } \\
\text { raised in Qatar }\end{array}$ \\
\hline Т 2 & Female & $\begin{array}{l}\text { Current teacher }(3 \\
\text { years) }\end{array}$ & $\begin{array}{l}\text { Primary, } \\
\text { Preparatory, } \\
\text { and Secondary }\end{array}$ & $\begin{array}{l}\text { Bachelor Education/ } \\
\text { English Language }\end{array}$ & $\begin{array}{l}\text { Born and } \\
\text { raised in Qatar }\end{array}$ \\
\hline T 3 & Female & $\begin{array}{l}\text { Current teacher ( } 3 \\
\text { years) }\end{array}$ & Primary & $\begin{array}{l}\text { Bachelor Education/ } \\
\text { Math and Science }\end{array}$ & Qatari \\
\hline $\mathrm{T} 4$ & Female & $\begin{array}{l}\text { Current teacher ( } 3 \\
\text { years) }\end{array}$ & Primary & $\begin{array}{l}\text { Bachelor Education/ } \\
\text { Math and Science }\end{array}$ & Qatari \\
\hline T5 & Female & $\begin{array}{l}\text { Current teacher ( } 3 \\
\text { years) }\end{array}$ & Primary & $\begin{array}{l}\text { Bachelor Education/ } \\
\text { Math and Science }\end{array}$ & Qatari \\
\hline T6 & Male & $\begin{array}{l}\text { Current teacher ( } 3 \\
\text { years) }\end{array}$ & Preparatory & $\begin{array}{l}\text { Bachelor Islamic } \\
\text { Studies/ University } \\
\text { in KSA }\end{array}$ & Qatari \\
\hline $\mathrm{T} 7$ & Male & $\begin{array}{l}\text { Current teacher (8 } \\
\text { Months) }\end{array}$ & Primary & $\begin{array}{l}\text { Bachelor Shariah \& } \\
\text { Islamic in KSA }\end{array}$ & Qatari \\
\hline $\mathrm{T} 8$ & Male & $\begin{array}{l}\text { Current teacher ( } 3 \\
\text { years) }\end{array}$ & Primary & $\begin{array}{l}\text { Bachelor Shariah \& } \\
\text { Islamic in KSA }\end{array}$ & Qatari \\
\hline T9 & Male & $\begin{array}{l}\text { Left teaching ( } 2 \\
\text { months)-Teach for } \\
\text { Qatar }\end{array}$ & Preparatory & $\begin{array}{l}\text { Bachelor Texas } \\
\text { A\&M/ Mechanical } \\
\text { Engineering }\end{array}$ & Qatari \\
\hline $\mathrm{T} 10$ & Male & $\begin{array}{l}\text { Left teaching ( } 2 \text { years)- } \\
\text { Teach for Qatar* }\end{array}$ & Preparatory & $\begin{array}{l}\text { Bachelor Chemical } \\
\text { Engineering }\end{array}$ & Qatari \\
\hline $\mathrm{T} 11$ & Male & $\begin{array}{l}\text { Left teaching ( } 2 \text { years)- } \\
\text { Teach for Qatar }\end{array}$ & Preparatory & $\begin{array}{l}\text { Bachelor Mechanical } \\
\text { Engineering }\end{array}$ & Qatari \\
\hline $\mathrm{T} 12$ & Female & Left teaching ( 2 years) & Primary & $\begin{array}{l}\text { Bachelor Education/ } \\
\text { English Language }\end{array}$ & $\begin{array}{l}\text { Born and } \\
\text { raised in Qatar }\end{array}$ \\
\hline $\mathrm{T} 13$ & Female & $\begin{array}{l}\text { Left teaching } \\
\text { (months)) }\end{array}$ & Primary & $\begin{array}{l}\text { Bachelor Education/ } \\
\text { English Language }\end{array}$ & Qatari \\
\hline T14 & Female & $\begin{array}{l}\text { Left teaching (3 years)- } \\
\text { Teach for Qatar }\end{array}$ & Preparatory & $\begin{array}{l}\text { Bachelor Social } \\
\text { Work }\end{array}$ & Qatari \\
\hline T15 & Female & $\begin{array}{l}\text { Left teaching ( } 2 \text { years)- } \\
\text { Teach for Qatar }\end{array}$ & Preparatory & $\begin{array}{l}\text { Bachelor Social } \\
\text { Work }\end{array}$ & Qatari \\
\hline
\end{tabular}




\section{Appendix B}

Sample of interview questions:

- Teachers who still working in teaching field

1) Could you please tell me something about your background? For example, Educational background, past teaching experiences, how long have been working in Qatari schools and the current schools.

2) How do you describe your daily life of being a young teacher in Qatari governmental school?

3) How do you feel about your confidence and qualification in managing the job (specifically in your teaching career)?

4) What are the challenges that you have faced so far as a young teacher?

5) What are the reasons of these challenges from your opinion?

6) Where do you go/whom do you ask when you have any questions or if you need help?

7) Do you feel that the training prepared you well for your job? And what other support needs might be helpful for your teaching career?

8) What is your career plan in the future?

9) Anything else you would like to address.

- Teachers who left the teaching field

1) Could you please tell me something about your background? For example, Educational background, past teaching experiences, how many years have you lived in Qatar? How long have been working in Qatari governmental schools as a teacher before you changed your job?

2) Do you get any pre-service education or training before you been a teacher?

3) Could you provide me with some reasons behind leaving the teaching career?

4) What do you think the reasons behind the challenges that novice teachers are facing in their daily life of teaching?

5) When you had some challenges, who do used to ask for help?

6) Anything else you would like to address? 